\title{
Strobilanthes crispus Juice Concentrations and Anticancer Effects on DNA Damage, Apoptosis and Gene Expression in Hepatocellular Carcinoma Cells
}

\author{
Faridah Hussin ${ }^{1}$, Sima Ataollahi Eshkoor ${ }^{2}$, Asmah Rahmat ${ }^{1 *}$, Fauziah Othman ${ }^{1}$, \\ Abdah Akim1, Zolkapli Eshak ${ }^{3}$
}

\begin{abstract}
Background: Hepatocellular carcinoma is one of the most common cancers worldwide. Its prevalence is increasing in many countries. Plant products can be used to protect against cancer due to natural anticancer and chemopreventive constituents. Strobilanthes crispus is one of plants with potential chemopreventive ability. Objective: This study aimed to evaluate the anticancer effects of Strobilanthes crispus juice on hepatocellular carcinoma cells. Materials and Methods: MTT assays, flow cytometry, comet assays and the reverse transcriptionpolymerase chain reaction (RT-PCR) were used to determine the effects of juice on DNA damage and cancer cell numbers. Results: This juice induced apoptosis after exposure of the HepG2 cell line for $72 \mathrm{~h}$. High percentages of apoptotic cell death and DNA damage were seen at the juice concentrations above $0.1 \%$. It was found that the juice was not toxic for normal cells. In addition, juice exposure increased the expression level of c-myc gene and reduced the expression level of c-fos and c-erbB2 genes in HepG2 cells. The cytotoxic effects of juice on abnormal cells were in dose dependent. Conclusions: It was concluded that the Strobilanthes crispus juice may have chemopreventive effects on hepatocellular carcinoma cells.
\end{abstract}

Keywords: Apoptosis - DNA damage - gene expression - hepatocellular carcinoma - Strobilanthes crispus juice

Asian Pac J Cancer Prev, 16 (14), 6047-6053

\section{Introduction}

Hepatocellular carcinoma (HCC) is one of the most frequent carcinomas worldwide that is on the rise (Abdelaziz et al., 2014; Liu et al., 2014; Singh et al., 2014). It accounts for $80-90 \%$ of liver cancers caused by the uncontrolled proliferation of hepatocytes. The etiology of HCC is multifactorial including liver cirrhosis (60-80\% of HCCs), infection by hepatitis B and C viruses, primary hemochromatosis and the prolonged exposure to mycotoxins such as aflatoxin B1. The multistep hepatocarcinogenetic process of HCC contains inflammation, cell death, cirrhosis, regeneration, DNA damage and dysplasia, which finally result in HCC (Pitot, 1998; Thorgeirsson et al., 1998; Tannapfel and Wittekind, 2002; Hamilton and Aaltonen, 2004). Most causes of HCC are viral hepatitis infections including hepatitis $\mathrm{B}$ and $\mathrm{C}$ as well as hepatic cirrhosis commonly due to alcoholism (Kumar et al., 2003). Liver cancer is the second most common cancer in Southeast Asian nations and the second leading cause of cancer death. The respective incidence and mortality rates per 100,000 are 5.7 and 5.4 in Malaysia (Kimman et al., 2012). In
Peninsular Malaysia, liver cancer ranked 6th overall, $5^{\text {th }}$ in males and 9th in females (Omar et al., 2006). About two-thirds of cancers can be prevented through lifestyle modifications (Oliveria, 1997) and using herbal medicines, which is increasing along other alternative medications (Eisenberg et al., 1998). It has been demonstrated that herbal medicine can be used to prevent and treat diseases (Firenzuoli and Gori, 2007) like cancers due to natural anticancer and chemopreventive constituents (Kaur et al., 2009). Such products range from traditional and popular medicines to the use of standardized and titrated herbal extracts (Firenzuoli and Gori, 2007).

Malaysia is rich in herbal resources. One of these herbal medicines is Strobilanthes crispus, which has chemopreventive potential ability. It is a native plant growing in many countries such as Madagascar, Indonesia and Malaysia (Sunarto, 1997). This plant has protective effects against cancers such as breast and colorectal cancers (Awad et al., 2000; Awad and Fink, 2000), which can be due to the effects of plant compounds on the regulation of genes (Chong et al., 2012) such as c-myc, c-fos and c-erbB2 (Volm et al., 1992). C-myc gene biologically promotes cell cycle proliferation (Amati 
Faridah Hussin et al

et al., 2001; Nilsson et al., 2004). C-fos gene normally regulates cell cycle, cell differentiation and transformation in cells (Tesarika et al., 1999). In addition, the expression of c-fos gene is associated with the expression of c-erbB2 gene (Scott et al., 1991). However, this study aimed to determine the cytotoxicity and gene regulation effects of Strobilanthes crispus juice on HepG2 cell line regarding the prevention and treatment of HCC.

\section{Materials and Methods}

\section{Chemicals}

Human normal cell (Chang liver cell) and cancer cell (HepG2 cell) lines of liver were purchased from American Type Culture Collection (ATCC), Rockville, Maryland, USA. Furthermore, materials including Dulbecco's modified Eagle's medium (DMEM), dimethyl sulfoxide (DMSO), fetal calf serum, penicillin, streptomycin, PBS-EDTA, trypsin and propidium iodide were bought from Sigma Chemical Co. (Gibco, USA). Trypan blue dye and 3-(4,5-dimethylthiazol-2-yl)-2,5diphenyltetrazolium bromide (MTT) were purchased from Sigma Chemical Company (St. Louis, MO, USA). Falcon flasks for cell culture were taken from Nunc Co. Denmark. MasterPure ${ }^{\mathrm{TM}}$ RNA Purification Kit (Epicentre Technologies, Becton Dickinson Corp., Rutherford, New Jersey, USA) was used for RNA purification. All chemicals were with the highest pure grade available.

\section{Preparation of Strobilanthes crispus Juice}

The optimum formulation and processing parameter for herbal juice preparation was selected from the response surface methodology analysis. The project was undertaken at the Faculty of Medicine and Health Sciences in Universiti Putra Malaysia (UPM). Strobilantes crispus plant (Voucher No. AZ-6803) locally named Karang Jin. The leaves of plant were collected from Agricultural Conservatory Park, the Institute of Biosciences, UPM. After collection, leaves were weighed, washed, cut into small pieces and then deposited at the Institute of Biosciences, UPM. The leaves of plant were mixed with filtered water containing $0.1 \%(\mathrm{w} / \mathrm{w})$ sodium metabisulphite and then grounded into very fine particles using mechanical grinder. $14 \%$ of puree was mixed with $14 \%$ honey, $0.2 \%(\mathrm{w} / \mathrm{w})$ xanthan gum and homogenized using Homogenizer IKA II for $5 \mathrm{~min}$. After that, mixture was pasteurized at $80^{\circ} \mathrm{C}$ for $3 \mathrm{~min}$ using jacketed heater. The final products were hot-filled into sterilized glass bottle, cooled to a room temperature under running water and kept chilled for analysis.

\section{Cell culture and treatment}

All cell cultures were carried out in Microbiological Safety cabinet ERLA Esc Series Class II. Cells were grown in DMEM supplemented with $10 \%$ fetal bovine serum (GIBCO BRL), penicillin and streptomycin, which was incubated in the humidified incubator at $37^{\circ} \mathrm{C}$ with $5 \% \mathrm{CO}_{2}$ and $95 \%$ air. Cultures were regularly examined using inverted microscope. The suitable amount of cells was pipetted into cell culture flasks (Nunc, Denmark) in order to treat. Three flasks were used for each type of treatment. After that, flasks were incubated in a $5 \% \mathrm{CO}_{2}$ incubator (Sanyo, Japan) at $37^{\circ} \mathrm{C}$ for $24 \mathrm{~h}$. Then, HepG2 cells were treated with the Strobilantes crispus juice at $0.1,0.4$, and $1 \%$ concentrations. Cells were left again in a $5 \% \mathrm{CO}_{2}$ incubator at $37^{\circ} \mathrm{C}$ for $72 \mathrm{~h}$. The harvested cells were used to conduct experiments.

\section{The MTT assay}

MTT assay was used to analyze the proliferation of cells (Vega-Avila and Pugsley, 2011). HepG2 and Chang cell lines were detached and the viability of cells was determined by staining with trypan blue and then counted using a haemocytometer under inverted microscope (Olympus CK40, Japan). Cells were diluted with DMEM to yield a concentration of $1 \times 105$ cells $/ \mathrm{mL}$. Then, $100 \mu \mathrm{L}$ of this cell suspension was pipetted into a 96-well micro titer plate (Nunc, Denmark) and incubated in a $5 \% \mathrm{CO}_{2}$ incubator at $37^{\circ} \mathrm{C}$ for $24 \mathrm{~h}$ to allow cells attached to well. After that, cells were treated with $100 \mu \mathrm{L}$ of sterilized sample (filter using $0.2 \mu \mathrm{m}$; Schleicher and Schuell), which was prepared in different concentrations including $0.001,0.01,0.1,1.0$ and $10 \%$. The 96 well-plate was incubated in $\mathrm{CO}_{2}$ incubator for 24,48 and $72 \mathrm{~h}$. Then, 10 $\mu \mathrm{L}$ of MTT was pipetted into all wells and incubated for $4 \mathrm{~h}$. Finally, wells were added with $100 \mu \mathrm{L}$ of DMSO and the absorbance of assayed 96-well plate was read using Microplate absorbance reader Anthos Zenyth 340s. The absorbance of each sample was calculated by comparison with the untreated control.

\section{Flow cytometry}

After treatment, Flow cytometer Becton Dickinson FACStarPLUS was used to measure DNA content. Cells were initially treated with different concentrations including $0.1,0.4$, and $1 \%$ and incubated with $5 \%$ $\mathrm{CO}_{2}$ at $37^{\circ} \mathrm{C}$ for $72 \mathrm{~h}$. After that, cells were fixed by adding absolute ethanol, followed by adding $200 \mu \mathrm{g} /$ $\mathrm{mL}$ of DNase-free Rnase A and incubated at $37^{\circ} \mathrm{C}$ for 30 min. Then, $100 \mu \mathrm{L}$ of $1 \mathrm{mg} / \mathrm{ml}$ propidium iodide (light sensitive) was added to cells and then incubated at room temperature for 5-10 min. The untreated and treated cells were placed into 12 X $75 \mathrm{~mm}$ Falcon tubes and read on Becton Dickinson FACStarPLUS (Becton Dickinson, Franklin Lakes, NJ).

\section{Comet assay}

After treatment, cells were used for comet assay analysis. Experiment was performed based on a protocol after some modifications that was belongs to McKelveyMartin and colleagues (McKelvey-Martin et al., 1993). Every step was carried out under dimmed light to prevent cell damage from UV (Eshkoor et al., 2012). Frosted microscope slides were covered with $80 \mu \mathrm{L}$ of $1 \%$ normal melting agarose (NMA) in TAE buffer at $45^{\circ} \mathrm{C}$, then covered with cover slip and kept at $4^{\circ} \mathrm{C}$ for 5 min until agarose had been solidified. Approximately $75 \mu \mathrm{L}$ of $0.5 \%$ low melting point agarose (LMA) at $37^{\circ} \mathrm{C}$ was added to the pellet of cells suspended in $10 \mu \mathrm{L}$ of PBS and then cell suspension was rapidly pipetted onto the first (NMA) agarose layer. Slides were immersed in freshly prepared, cold lysis solution added with $1 \%$ triton $\mathrm{X}-100$ at $4{ }^{\circ} \mathrm{C}$ for 
$1 \mathrm{~h}$ in a dark place. After removing from lysis solution, slides were drained and immersed in electrophoresis buffer (10N NaOH, 200mM Na2EDTA, pH $>12$ ) that was at $4^{\circ} \mathrm{C}$ for 20 to $60 \mathrm{~min}$ in the dark to unwind DNA. Slides were placed flat on a gel tray with aligned equidistant from electrodes. Electrophoresis was conducted for $20 \mathrm{~min}$ at $25 \mathrm{~V}$ adjusted to $300 \mathrm{~mA}$. Slides were stained with $50 \mu \mathrm{L}$ of $20 \mu \mathrm{g} / \mathrm{ml}$ ethidium bromide and viewed using fluorescence microscope. Analysis was performed immediately after staining, using a Leica Epifluorescence microscope equipped with an excitation filter of 515-560 nm with magnification of $400 X$. For each sample population, 15-50 cells were considered to be analysed. Slides were scored by moving from top to bottom along the slide to avoid analysis of the same comet twice. The parameters of tail length (distance from the head center to the end of the tail) and tail migration (distance from the end of the head to the end of the tail) were used to estimate DNA migration.

\section{Gene Expression and RT-PCR}

Total RNA was extracted from the treated cells with Strobilanthes crispus juice. RNA was extracted according to the protocol of MasterPureTM RNA Purification Kit from Epicentre Technologies (Becton Dickinson Corp., Rutherford, New Jersey, USA). The extracted RNA was treated with DNase and then was used to synthesize cDNA by One Step RT-PCR that was based on RT-PCR Premix protocol (Mbiotech, Korea). In the current study, the genes of c-myc, c-fos and c-erb2 were investigated. Housekeeping genes including B-actin and $15 \mathrm{~s}$ were selected to act as internal positive control. PCR primers for c-myc gene were obtained from an article (Coucouvanis and Jones, 1993). Primers for c-fos, c-erb2, 15s and B-actin were designed. The sense primers for c-fos and c-erb2, c-myc, $15 \mathrm{~s}$ and $\beta$-actin genes were 5'-GGATAAGATGGCTGCAGCCAAGTGC-3', 5' - G A T G T A T T T G A T G G T G A C C T - 3', 5' - CAA-GAGGCGAACACACCACGTCT-3', 5'-TTCCGCAAGTTCACCTACC-3',5'-CGTGGGCGCCCTAGGCACCA-3' respectively. The respective antisense primers for c-fos and c-erb2, c-myc, $15 \mathrm{~s}$ and $\beta$-actin genes were 5'-AAGGAAGACGTGTAAGCAGTGCAGC-3', 5' - A T C T G G - C T G G T T C A C A T A T T - 3', 5' - AACTGTTCTCGTCGTTTCCGCAA-3', 5' - C G G G C C G G C C A - T G C T T T A C G - 3', 5'-TTGGCCTTAGGGTTCAGGGGGG-3'. PCR reaction included $1 \mathrm{ng}-2 \mu \mathrm{g}$ total RNA, $1 \mu \mathrm{L}$ of primer (10pmol/ $\mu \mathrm{L}), 10 \mu \mathrm{L}$ of One Step RT-PCR Premix Master Mix (5X) and $7 \mu \mathrm{L}$ of RNase-free water in a PCR reaction tube to have a volume of $20 \mu \mathrm{L}$. The reverse transcription was performed at $42^{\circ} \mathrm{C}$ within $30 \mathrm{~min}$ in one cycle followed by RT inactivation and pre-denaturation at $96^{\circ} \mathrm{C}$ for 3 min. The PCR reaction was continued for all samples with the same conditions within 30 cycles. Cycles were settled on a denaturation stage at $94^{\circ} \mathrm{C}$ for 30 s, annealing temperature at $50-60^{\circ} \mathrm{C}$ arranged based on the gradient PCR applicable for all primers for 30 s, an extension phase at $72^{\circ} \mathrm{C}$ for $60 \mathrm{~s}$ and a final extension at $72^{\circ} \mathrm{C}$ for $10 \mathrm{~min}$ followed the reaction last cycle.

After amplification, samples were stored at $4^{\circ} \mathrm{C}$ until use. A negative control without DNA template was also carried out in each run. The PCR products were analyzed by running products on $1.5 \%$ agarose gel electrophoresis. Besides, DNA ladder of 100 bp (Bioline, USA) were resolved to identify the size of products. The visualization of DNA was by placing gel onto UV light source. The quantity of RT-PCR bands was analyzed based on the intensity under Gel Doc 2000 software (BIO-RAD). Ratios of the target gene to reference gene (housekeeping gene) were calculated and compared.

\section{Statistical analyses}

Data were analysed using the Statistical Package for the Social Sciences (SPSS) software version 19.0 (Chicago, IL, USA). The critical level for rejection of the null hypothesis was considered to be a p value of 5\%, twotailed. Values were expressed as mean \pm SD. Data were statistically analyzed using one way ANOVA followed by Tukey's post Hoc analysis.

\section{Results}

The MTT assay results showed that the increased doses of juice up to $10 \%$ had no cytotoxic effects on Chang cell lines as indicated by absence of IC50 values when the cell lines were treated for up to $72 \mathrm{~h}$ incubation time (Figure 1). Furthermore, the findings indicated that juice was not toxic for normal cells. It was found that the Strobilanthes crispus juice inhibited the proliferation of HepG2 cancer cell lines based on the concentration and duration of exposure. The cytotoxicity effect of juice on cancer cells was started at $0.1 \%$ and an incubation time above 72 h. The growth inhibition effect of juice underlying cell death or growth arrest was determined by cell staining with propidium iodide (PI) in Fluorescence-activated cell sorting (FACS) analysis. The results showed that apoptotic death as cell death and the number of sub-G1 population increased in the treated HepG2 cell lines with juice. The effect of juice to induce apoptosis in HepG2 cell lines was correlated with the concentration of juice and duration of exposure. The higher percentage of apoptotic cells than normal cells was started at a concentration more

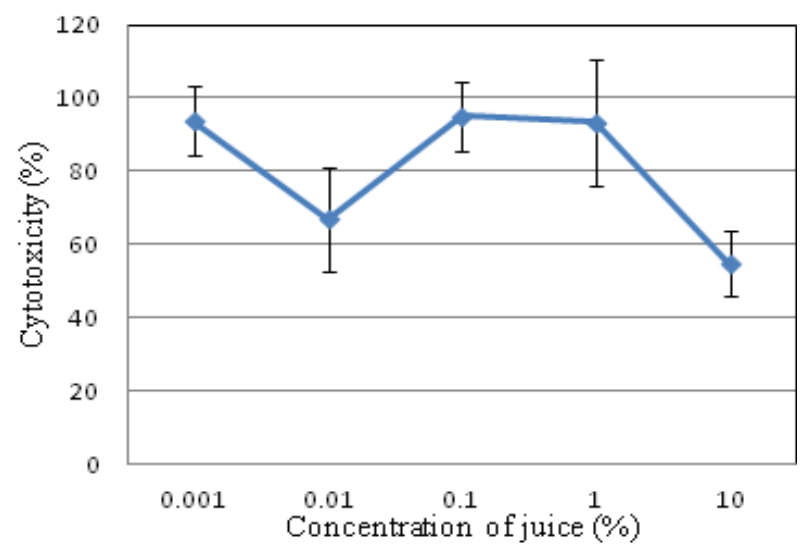

Figure 1. The Cytotoxic Effects of Strobilanthes Crispus Juice on Chang Liver Cell line via MTT-assay. Cells were seeded in 96-well plates at a density of $10^{5}$ and treated with filtered Strobilanthes crispus juice for $72 \mathrm{~h}$. Values are presented as means $(n=3) \pm S$.E 


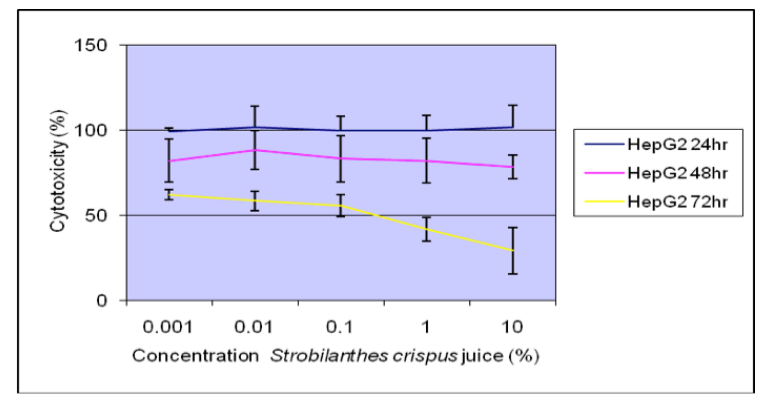

Figure 2. The Effect of Strobilanthes Crispus Juice on HepG2 Cell Lines via MTT-assay. Cells were seeded in 96-well plates at a density of 105 and treated with filtered Strobilanthes crispus juice $(0.001-10 \%)$ for 24,48 and $72 \mathrm{hr}$. Values are presented as means $(\mathrm{n}=3) \pm$ S.D

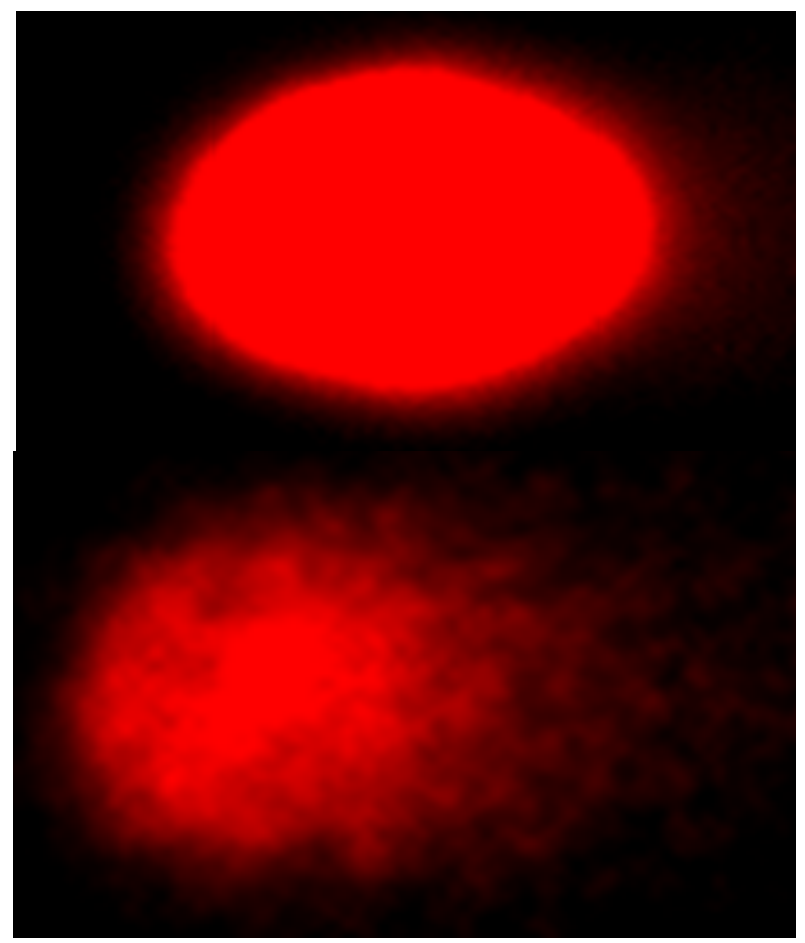

Figure 3. Fluorescence Image of Red-Stained Comets from Control (I) and Juice Treated (II) HepG2 Cell (20X magnification)

than $0.1 \%$ and an incubation time for $72 \mathrm{~h}$. It was found that cell death in HepG2 cell lines compared to normal cells increased 5, 7 and 10 fold at the concentrations of $0.1,0.4$ and $1.0 \%$ respectively. As HepG2 cells treated with the Strobilanthes crispus juice, G1 phase increased at the concentration up to $0.4 \%$ and decreased to about $65 \%$ cell populations, however, was higher than control cells $(48 \%)$. The treatment of cells with juice significantly increased sub G1 phase from $3 \%$ to $25 \%$ and decreased $\mathrm{G} 2 / \mathrm{M}$ phase from $33 \%$ to $7 \%(\mathrm{p}<0.01)$. The results of comet assay identified the level of DNA damage induced by the Strobilanthes crispus juice (Figure 2). Following the treatment with juice at different concentrations of $0.1,0.4$ and $1.0 \%$ for $72 \mathrm{~h}$, DNA damage significantly increased in HepG2 cells in relation to dose level $(\mathrm{p}<0.05)$. A marked induction of DNA damage was significantly observed at the concentration dose above $0.1 \%(\mathrm{p}<0.05)$. The findings indicated that DNA damage slightly increased at the concentrations from $0.1 \%$ to $0.4 \%$, which indicated dosage

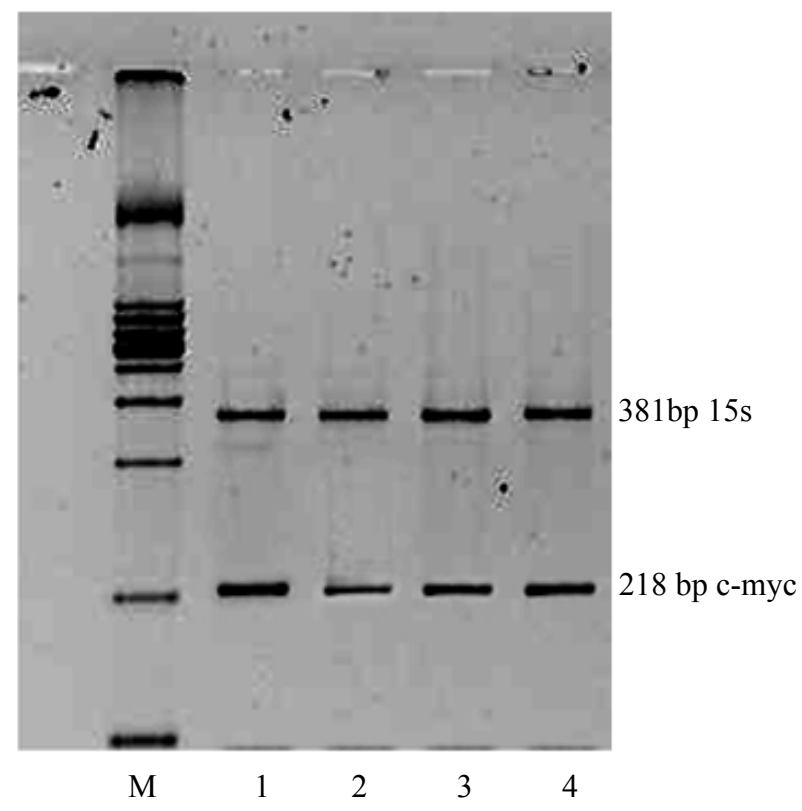

Figure 4. Expression of C-Myc Oncogene in Untreated (1) and Treated $(2,3,4)$ HepG2 Cancer Cell Lines with 0.1,0.4,1.0\% Strobilanthes Crispus Juice Respectively for $72 \mathbf{h}$. Note the expression of c-myc band before (1) and after treatment $(2,3,4)$. Lane $\mathrm{M}$ is the DNA ladder for marker and act as comparison to the oncogene band

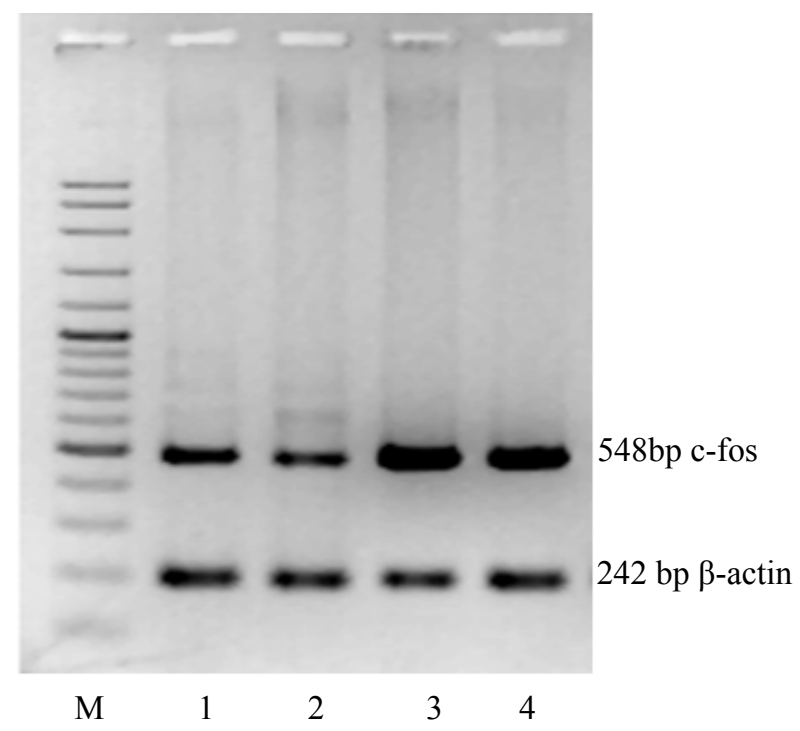

Figure 5. Expression of c-fos Oncogene in Untreated (1) and Treated $(2,3,4)$ HepG2 Cancer Cell Lines with 0.1,0.4, 1.0\% Strobilanthes Crispus Juice Respectively for $72 \mathbf{h}$. Note the expression of c-fos band before (1) and after treatment $(2,3,4)$. Lane $M$ is the DNA ladder for marker and act as comparison to the oncogene band

ability to induce DNA damage.

The findings obtained from RT-PCR showed mRNA expression of oncogenes in HepG2 cell lines. The expression of oncogenes and housekeeping genes was evaluated at three different concentrations of juice including low, medium and high. The respective sizes of c-myc, c-fos and c-erbB2 oncogenes were 218, 584 and $182 \mathrm{bp}$ whereas $15 \mathrm{~S}$ and $\beta$-actin housekeeping genes were 381 and 242 bp respectively (Figure 3-5). Housekeeping genes $(\beta$-actin and $15 \mathrm{~S})$ were expressed in both treated 


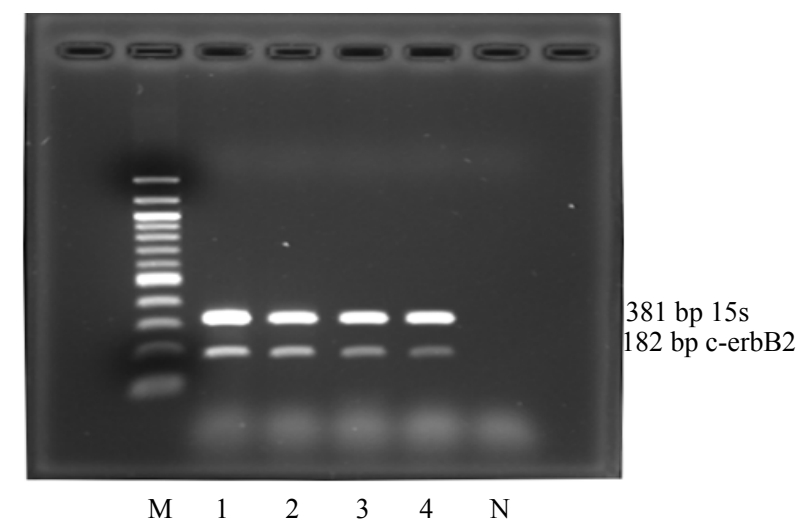

Figure 6. Expression of c-erbB2 Oncogene in Untreated (1) and Treated $(2,3,4)$ HepG2 cancer cell lines with 0.1,0.4, 1.0\% Strobilanthes Crispus Juice Respectively for $\mathbf{7 2} \mathbf{h}$. Note the expression of c-erbB2 band before (1) and after treatment $(2,3,4)$. Lane $\mathrm{M}$ is the DNA ladder for marker and act as comparison to the oncogene band

Table 1. Ratio of Target Genes to Reference Genes Expression in Untreated and Treated HepG2 Cell Line with the Strobilanthes Crispus Juice

\begin{tabular}{|c|c|c|c|}
\hline \multirow{2}{*}{$\begin{array}{l}\text { Concentration of } \\
\text { Strobilanthes } \\
\text { crispus juice (\%) }\end{array}$} & & \multicolumn{2}{|c|}{$\begin{array}{l}\text { Expression of oncogenes } \\
\text { in HepG2 }\left(\mathrm{INT} / \mathrm{mm}^{2}\right)\end{array}$} \\
\hline & c-myc & c-fos & c-erbB 2 \\
\hline 0 & 0.76 & 0.55 & 0.76 \\
\hline 0.1 & 1.28 & 0.91 & 0.55 \\
\hline 0.4 & 1.15 & 0.42 & 0.53 \\
\hline 1 & 1.25 & 0.42 & 0.48 \\
\hline
\end{tabular}

and untreated cells. However, the results showed that various concentrations of juice up-regulated c-myc gene expression and suppressed c-fos and c-erb B2 genes in the treated cells compared to their respective controls, which was dose-dependent (Table 1).

\section{Discussion}

In vitro cytotoxicity assay is applied to exhibit potential antioxidant and anticancer properties of plant extracts (Ju et al., 2004; Moongkarndi et al., 2004), which prevent the proliferation of multiple human cancer cells (Magiatis et al., 2001; Kazi et al., 2003). One of these plants is Strobilanthes crispus, which could inhibit proliferation of HepG2 cells in a dose dependent manner and exposure duration. Such effect is probably attributed to the presence of polyphenols and bioactive compounds including $\beta$-sitosterol and stigmasterol in herb. The findings were in the line with existing reports indicating the antiproliferative and cytotoxic effects of Strobilanthes crispus on retroviruses (Kusumoto et al., 1992) and cancers such as colon (Normen et al., 2001), colorectal, breast, liver (Awad et al., 2000) and lung (Li et al., 2004). In the current study, the MTT assay evaluated the cytotoxic effects of Strobilanthes crispus juice on Chang cell lines as control and HepG2 cancer lines to indicate the inhibition level of cell growth. Apparently, the chemoprevention activity of juice treatment toward HepG2 cell line was due to more susceptibility of cancer cells to treatment compared to normal cell line.

In addition, the antiproliferative activity of juice was determined using flow cytometry and comet assay. The treatment of HepG2 cells with juice increased DNA damage and apoptosis in cells in a dose dependent manner (Nicoletti et al., 1991). Such cancer protective effects was probably due to non-dietary antioxidants in juice (Cai et al., 2000; Park et al., 2003). This study confirmed that the Strobilanthes crispus juice was not a potent cytotoxic (Geran, 1972). Thus, this juice seems safe for consuming in healthy people to prevent the liver cancer. The findings showed that juice increased c-myc gene expression in the treated HepG2 cells, which was probably associated with the efficient induction of apoptosis (Dong et al., 1997) and regulation (Tiberio et al., 2001). Over-expression of c-myc gene in cancers can cause increased apoptotic program and cell death in the cells deprived of survival factors (Tiberio et al., 2001). Despite our results, the contribution of c-myc oncogene to the regulation of cell death and apoptosis (Thompson, 1998) can be expressed in both levels up and down (Dong et al., 1997; Tiberio et al., 2001). Apparently, certain elements such as cell types affect the levels of gene expression (Robson et al., 2011). In addition, the treatment of HepG2 cells with the Strobilanthes crispus juice decreased c-fos gene expression, which was probably due to the G0/G1 transition, cell cycle progression (Kovary and Bravo, 1991) and contribution to transduction of signals induced by growth and differentiation factors or external stimuli (Obata et al., 2003). Furthermore, decreased expression of c-erbB2 gene in HepG2 cells after treatment may be explained by the contribution of gene to differentiation, apoptosis (Yu and Hung, 2000) and c-myc-mediated apoptosis (Kalra and Kumar, 2004). Down regulation of c-myc and c-erbB2 oncogenes can also be related to the factors of serum starvation, chemically induction and exposure to virus (Landay et al., 2000; Li et al., 2001). Our results confirmed a previous research (Kalra and Kumar, 2004) indicating the correlation between c-fos or c-myc oncogene and apoptosis. In addition, our study confirmed the existing reports, which indicated the contribution of lower expression of c-erbB2 oncogene in apoptosis (Landay et al., 2000).

Contradictory reports of study were those found down regulation of c-myc (Landay et al., 2000; Li et al., 2001) or up regulation of c-fos in apoptosis (Hu et al., 1996; Inada et al., 1998). Such findings suggest that the Strobilanthes crispus juice can interfere with oncogenes in the liver cancer cells. However, the expression level of genes depends on cell-type specificity and the nature of the apoptotic stimuli such as drugs and compounds. External stimuli can cause the impairment of oncogene activities and block oncogenes to induce apoptosis. Apparently, genetic alterations including up or down expression of oncogenes are related to signal transduction pathways and apoptosis in cell lines (Kalra and Kumar, 2004). It seems that sodium metabisulphite used to degrade green pigments and remove polyphenols as well as polysaccarids has dual effects on cells (Pedrosa and Soares-da-Silva, 2002; Dani et al., 2007). However, these results suggest that the extract of this herbal can be used as a potential 
natural chemopreventive agent to combat the liver cancer.

It was concluded that the Strobilanthes crispus juice could inhibit the proliferation of HepG2 cell line with the involvement of apoptosis or programmed cell death. The herbal juice significantly reduced DNA damage in cells when was exposed for $72 \mathrm{~h}$. Furthermore, this juice increased c-myc gene expression and reduced the level of c-fos and c-erbB2 genes in HepG2 cells, which could enhance apoptosis in the cells. However, this study suggests that daily regularly intake of moderate quantities of the Strobilanthes crispus juice can maintain a healthy liver and reduce the risk of cancer.

\section{Acknowledgements}

Authors would like to thank laboratory staff for providing support during the study

\section{References}

Abdelaziz AO, Elbaz TM, Shousha HI, et al (2014). Survival and prognostic factors for hepatocellular carcinoma: an Egyptian multidisciplinary clinic experience. Asian Pac J Cancer Prev, 15, 3915-20.

Amati B, Frank SR, Donjerkovic D, et al (2001). Function of the c-myc oncoprotein in chromatin remodeling and transcription. Biochim Biophys Acta, 1471, 135-45.

Awad A, Downie A, Fink C (2000). Inhibition of growth and stimulation of apoptosis by beta-sitosterol treatment of MDA-MB-231 human breast cancer cells in culture. Intl $J$ Molecular Med, 5, 541 .

Awad AB, Fink CS (2000). Phytosterols as anticancer dietary components:evidence and mechanism of action. $J$ Nutrit, 130, 2127-30.

Cai Y, Lua Q, Sun M, et al (2000). Antioxidant activity and phenolic compounds of 112 traditional Chinese medicinal plants associated with anticancer. Life Sci, 74, 2157-84.

Chong HZ, Rahmat A, Yeap SK, et al (2012). In vitro cytotoxicity of Strobilanthes crispus ethanol extract on hormone dependent human breast adenocarcinoma MCF-7 cell. BMC Complem Alternat Med, 12, 35.

Coucouvanis EC, Jones PP (1993). Changes in protooncogene expression correlated with general and sex specific differentiation in murino primordial germ cells. Mech Dev, 42, 49-58.

Dani C, Vestri V, Bertini G, et al (2007). Toxicity of corticosteroids and catecholamines for mice neuronal cell cultures: Role of preservatives. J Maternal-Fetal Neonatal Med, 20, 325-33.

Dong JM, Naito Y, Tsuruo T (1997). C-myc play a role in cellular susceptibility to death receptor-mediated and chemotherapyinduced apoptosis in human monocytic leukemia U937 cells. Oncogene, 15, 639-47.

Eisenberg DM, Davis RB, Ettner SL (1998). Trends in alternative medicine use in the United States, 1990-1997. JAMA, 280, 1569-75.

Eshkoor SA, Ismail P, Abd.Rahman S, et al (2012). The Association of DNA Damage Level with Early Age at the Occupational Exposure in the Mechanical Workshops Workers. Asian J Biotechnol, 4, 83-91.

Firenzuoli F, Gori L (2007). Herbal medicine today: Clinical and Research Issues. eCAM, 4, 37-40.

Geran R (1972). Protocols for screening chemical agents and natural products against animal tumors and other biological systems. Cancer Chemother Rep, 3, 51-61.

Hamilton SR, Aaltonen LA (2004). Pathology and genetics: tumors of the digestive system. Lyon: IARC; 2000. 1010 C. Alexia et al. Biochemical Pharmacol, 68, 1003-15.

$\mathrm{Hu}$ L, Hatano M, Ruther U, et al (1996). Overexpression of c-Fos induces apoptosis of CD43+ pro-B cells. J Immunol, 157, 3804-11.

Inada K, Okada S, Phuchareon J, et al (1998). C-Fos Induces Apoptosis in Germinal Center B Cells. J Immunol, 161, 3853-61.

Ju EM, Lee SE, Hwang HJ, et al (2004). Antioxidant and anticancer activity of extract from Betula platyphylla var. japonica. Life scien 74, 1013-26.

Kalra N, Kumar V (2004). C-fos is a mediator of the c-mycinduced appoptitic signaling in serum-deprived hepatoma cells via the p38 mitogen-activated protein kinase pathway. J Biological Chem, 279, 25313-9.

Kaur M, Agarwal C, Agarwal R (2009). Anticancer and cancer chemopreventive potential of grape seed extract and other grape-based products. $J$ Nutrit 139, 1806-12.

Kazi A, Urbizu DA, Kuhn DJ, et al (2003). A natural musaceas plant extract inhibits proteasome activity and induces apoptosis selectively in human tumor and transformed, but not normal and non-transformed, cells. International $J$ Molecular Medicine, 12, 879-88.

Kimman M, Norman R, Jan S, et al (2012). The burden of cancer in member countries of the Association of Southeast Asian Nations (ASEAN). Asian Pac J Cancer Prev, 13, 411-20.

Kovary K, Bravo R (1991). The c-jun and c-fos protein families are both required for cell cycle progression in fibroblast. Molecular Cell Biol, 11, 4466-72.

Kumar V, Fausto N, Abbas A (2003). Robbins \& Cotran Pathologic Basis of Disease, $7^{\text {th }}$, Saunders. 914-7.

Kusumoto JT, Shimada I, Kakiuchi N, et al (1992). Inhibitory effects of Indonesian plant extracts on reverse trancriptase of an RNA tumour virus (I). Phytotheraphy Res, 6, 241-4.

Landay M, Oster SK, Khosravi F, et al (2000). Promotion of growth and apoptosis in c-myc nullizygous fibroblasts by other members of the myc oncoprotein family. Cell Death Differ, 7, 697-705.

Li D, Tonya M, Shinji S (2001). AFP-L3: a new generation of tumor marker for hepatocellular carcinoma. Clinica chemica acta, 313, 15-9.

Li SS, Gao Z, Feng X, et al (2004). Plant sterols as selective DNA polymerase beta lyase inhibitors and potentiators of bleomycin cytotoxicity. Bioorganic Med Chem, 12, 4253-8.

Liu M, Jiang L, Guan X-Y (2014). The genetic and epigenetic alterations in human hepatocellular carcinoma: a recent update. Protein Cell, 5, 673-91.

Magiatis P, Pratsinis H, Kalpoutzakis E, et al (2001). Hydrolyzable tannins, the active constituents of three Greek Cytinus taxa against several tumor cell lines. Biological Pharmaceutical Bulletin, 24, 707-9.

McKelvey-Martin VJ, Green MHL, Schmezer P, et al (1993). The single cell gel electro (comet assay): A European review. Mutat. Res, 288, 47-63.

Moongkarndi P, Kosem N, Kaslungka S, et al (2004). Antiproliferation, antioxidation and induction of apoptosis by Garcinia mangostana (mangosteen) on SKBR3 human breast cancer cell line. J ethnopharmacol, 90, 161-6.

Nicoletti I, Migliorati G, Pagliacci MC, et al (1991). A rapid and simple method for measuring thymocyte apoptosis by propidium iodide staining and flow cytometry. $J$ Immunological Methods, 139, 271-9.

Nilsson JA, Maclean KH, Keller UB, et al (2004). Mnt loss triggers Myc transcription targets, proliferation, apoptosis, and transformation. Molecular Cellular Biol, 24, 1560-9.

Normen AL, Brants HA, Voorrips LE, et al (2001). Plant sterol intakes and colorectal cancer risk in the Netherlands Cohort 
Study on Diet and Cancer. Am J Clin Nutrit, 74, 141-8.

Obata S, Okada S, Ohkubo Y, et al (2003). Over expression of the c-fos gene perturbs functional maturation of MI cells into macrophages. Molecular immunol, 39, 585-94.

Oliveria SA (1997). The Role of Epidemiology in Cancer Prevention. Soc Exp Bio Med, 216, 142-50.

Omar ZA, Ali ZM, Tamin NSI (2006). Malaysian cancer statistics - data and figureure peninsular Malaysia

Park YK, Park E, Kim JS, Kang MH (2003). Daily grape juice consumption reduces oxidative DNA damage and plasma free radical levels in healthy Koreans. Mutat Res, 529, 77-86.

Pedrosa R, Soares-da-Silva P (2002). Oxidative and nonoxidative mechanisms of neuronal cell death and apoptosis by L-3, 4-dihydroxyphenylalanine (L-DOPA) and dopamine. British J Pharmacol, 137, 1305-13.

Pitot HC (1998). Hepatocyte death in hepatocarcinogenesis. Hepatol, 28, 1-5.

Robson S, Ward L, Brown H, et al (2011). Deciphering c-MYCregulated genes in two distinct tissues. BMC genomics, $\mathbf{1 2}$, 476.

Scott G, Dodson J, Montgomery P, et al (1991). p185HER2 signal transduction in breast cancer cells.J Biological Chem, 266, 14300-5.

Singh S, Singh PP, Roberts LR, et al (2014). Chemopreventive strategies in hepatocellular carcinoma. Nature Reviews Gastroenterol Hepatol, 11, 45-54.

Sunarto PA (1997). Material medika indonesia. $1^{\text {st }}$ ed. Pp. 9599. Jakarta: penerbit direktorat jenderal pengawasan obat dan makanan.

Tannapfel A, Wittekind C (2002). Genes involved in hepatocellular carcinoma:deregulation in cell cycling and apoptosis. Virchows Arch, 440, 345-52.

Tesarika J, Garrigosa L, Mendoza C (1999). Estradiol modulates breast cancer cell apoptosis: a novel nongenomic steroid action relevant to carcinogenesis. Steroids, 64, 22-7.

Thompson EB (1998). The many roles of c-Myc in apoptosis. Annual Review Physiol, 60, 575-600.

Thorgeirsson SS, Teramoto T, Factor VM (1998). Dysregulation of apoptosis in hepatocellular carcinoma. Seminar Liver Dis, 18, 115-22.

Tiberio L, Maier JAM, Schiaffonati L (2001). Down-modulation of c-myc expression by phorbol ester protects CEM T leukaemia cells from starvation-induced apotosis: role of ornithine decarboxlase and polyamines. Cell Death Differentiat, 8, 967-76.

Vega-Avila E, Pugsley MK ( 2011). An Overview of Colorimetric Assay Methods Used to Assess Survival or Proliferation of Mammalian Cells. Proc West Pharmacol Soc, 54, 10-4.

Volm M, Efferth T, Mattern J (1992). Oncoprotein (c-myc, c-erbB1, c-erbB2, c-fos) and suppressor gene product (p53) expression in squamous cell carcinomas of the lung. Clinical and biological correlations. Anticancer Res, 12, 11.

Yu D, Hung MC (2000). Overexpression of ErbB2 in cancer and ErbB2-targeting strategies. Oncogene, 19, 6115-21. 